\title{
STUDENTS' PERCEPTION OF PERFOMANCE-BASED ASSESSMENT APPLICATION IN HIGHER EDUCATION
}

\author{
Amalul Umam ${ }^{1}$, Fidini Peparing $\mathbf{M}^{2}$, Muhammad Kiki Wardana ${ }^{3}$ \\ Universitas Ibn Khaldun Bogor ${ }^{1,2}$, Universitas Harapan Medan ${ }^{3}$ \\ $\underline{{ }^{1} \text { amalul.umam@uika-bogor.ac.id, }}{ }^{2}$ fidinimauludhy08@gmail.com, ${ }^{3}$ muhammadkikiwardana@gmail.com
}

\begin{abstract}
Learning process needs to be well-planned by the teachers in $21^{\text {st }}$ century. It aims to build the students' character to be more professional facing social-life problem. To evaluate, Performance-Based Assessment (PBA) has been implemented by many states which emphasizes the performance-skills of demonstrating ideas such as presentations, debate, making papers, shows etc. Its function of engaging students' interest in subject and as teachers' way of assessing students' capability. For college students, doing group presentation has been done in many times and mostly implemented as assignments. However, students' opinions toward this assessment must be important case for teachers' evaluation. This paper is made to find out and analyze students' perception on PBA in university level.
\end{abstract}

Keywords: Assessment, Higher education, PBA, Students' perception

\section{Introduction}

In $21^{\text {st }}$ century, there are four competencies which the students must have (4C): 1.) Critical thinking and problem solving; 2.) Creativity and Innovation; 3.) Communication; 4.) Collaborative (Erdogan, 2019). For the first, it means that students are able to think critically when they face some cases which must be overcome. As example, students of EFL class that is assigned to find English reading materials which is for the needs of academic writing, they may not just copy and paste the materials randomly. They must look for them in credibledsource which support the research. For the second, it means that the students must have the qualilty of creating something by their own rather than imitated. For example, pre-service teachers who make their own syllabus for teaching. For the third, it means that students are able to share ideas by communicating with people. This ability is needed to expand of network of occupation. For recenly years, a public speaking class is taken by a lot of people. For the forth, it means students are requested to work in group to learn how to combine personal thoughts with group thoughts, how to unite them and take the best decision together. The significance of how these skills are put in education related to some studies for many years: (Fajriah \& Septiyanti, 2021) in EFL class, (Hidayatullah etc, 2021) in Physics Education, (Suyitno etc, 2021) for mathematic online learning, (Masriani etc, 2021) the relationsip between 4C and HOTS (High Order Thinking Skills for science teachers. Based on the previous studies which have been mentioned, it indicates that $4 \mathrm{C}$ and educational fields are important case as the focus for recently years.

In this situation, the needs of choosing the right learning methodologies is necessary for every role in education as the way to achieve the goal of curriculum. Also in learning process, there is also a step of students' evaluation as the process of teachers measure students' ability of mastering the given materials. This step is defined as assessment. As many people know that it is done by testing the studentst on how they comprehend the subject. For example, an assessment of end of the year or it is called as PAT (Penilaian Akhir Tahun), this is applied in some educational levels in Indonesia, which are elementary school, junior high scool, and senior high school. However, for daily assessment, some teachers are still confused to use what kind of assessment which depends on the $4 \mathrm{C}$ abilities. A traditional 
assessment system in higher education, using alpha-numeric letter grades on " $A$ " up to " $F$ " which does not have guideliness how to assess the students based on the standard (Newton etc, 2020). Also a study of formative e-assessment makes the researchers are confused how to decide what formative e-assessment strategy as the most preferred choice (Bahati etc, 2019).

Performance-Based Assessment is one of assessment that is mostly implemented in highereducation such as doing presentaion in group. The benefits can be related to the $4 \mathrm{C}$ abilities. Students are assigned to perform what they have learned by themeselves in front of other friends as audiences. Some studies about presentation as PBA (Performance-Based Assessment) have been conducted for many times, a study of students' behaviour in a group presentation (Fekry etc, 2019), assessing oral presentation performance (Van Ginkel etc, 2017), students' efficay of English speaking skill (Atayeva, 2019). This means that doing presentation in group have been considered as an assessment which are frequently done in many classess.

However, the students' perception of PBA are also necessary to be considered as well. So that, this study is planned to investigate on how students think about this assessment that is particularly used in the level of higher education. As the hope of the researchers, this study is able to be as documents to support the better teaching performance of some lecturers or teachers. It is as the source of evaluation of teachers' feedback on how they teach in classroom.

\section{Definition of Assessment}

Assessment is activity of collecting, analyzing, and translating the students' capability in any objectives. It is as a basic part of teaching and learning environment (Murchan \& Shiel, 2017). Teachers in class do not just teach the subject materials to the students. They are also assigned to measure students' capability on how they master the lesson and evaluate them. This activity also boost students to learn the given knowledge as well. There are many studies about assessment which have been implemented for many years and regions. As examples, in Romania (Hannah etc, 2017), in UK (Elis etc, 2017), in Uzbekistan (Muradkasimova, 2021).

\section{Assessment Types}

It is divided to be two parts, namely formative assessment and summative assessment. Formative means that the teachers assess the students during learning process to get information of students' background. For example, when English teachers intends to check students' vocabularies, the teachers speak full english in class, and see how students do based on the commandment. Do the students respon well on teachers' willing? Or are the students silent?. Meanwhile, summative assessment means that the teachers held the test after the class is done or routinely every week, every month or even in a year (Broucher \& Creech, 2021)

\section{Principles of Assessment}

Some principles of assessmet includes (Brown, 2004) : 1.) Praticality. It means that the assessment is not expensive, not taking long-time, uncomplicated such as a multiple choice type test of Introduction materials. To give score is also easy for teachers to do; 2.) Authenticity. It is when teachers command the students to do the things which are related to the activity happens in real-life. It is beneficial to do in daily life. For examples, doing presentation, being a vlogger, writing short-story or scientific paper. So that, when teachers ask the students to mention vocabularies in classroom, this is not called as authenticity; 3 .) Washback. This is students' effect on how they do through assessment. Does it burden them? Make them stressed? Confusing? Or too easy?; 4.) Validity. This means what is tested is related to the learning materials that is given to them; 5.) Realibility. This means that the 
assessment is dependable. It is qualified to measure students' ability of mastering the materials. For example, TOEFL.

\section{Performance-Based Assessment}

It is one kind of assessment in which the students are asked to express thoughts or the thing they have mastered by showing them in front of the teachers. When the teachers intend to get the results of learning which the students can do the solving-problems and darely share thoughts orally, PBA fits the situation. When teahers intend to measure student's ability of driving skill as example, do not do the multiple choice test, but performance test. This also happen when students are assign to the things whichare related to the abilities of $4 \mathrm{C}$ in $21 \mathrm{st}$ century. The abilities need more in practice. There are some researchs have been implemented around regions, such as in the level of graduate teacher (Wyatt-Smith, 2018), in the level of pre-school in Yogyakarta (Syah \& Hermawati, 2018), among pre-service teachers and in-service teachers (Jeschke etc, 2019) and also even in the field of phisycal education of badminton (Casebolt \& Zhang, 2020).

\section{Higher Education Curiculum in Indonesia}

Stated in Laws of The Republic Indonesianumber 12 year 2012about Higher Education that Higher Education must have the principle of student-centered learning withpay attention to the environment in harmony and balanced. This means that PBA is match with the Indonesian government rules of college students that the learning process including assessment is to use the form of student-centered. This happens when students are given rights by lecturers orally share what they have learnt before. Also in the rules states that students as members of the Academic Civitaspositioned as an adult human who hasselfawareness in developing self-potentialin College to become intellectual,scientists, practitioners, and/or professionals. This also supports PBA as the way of teachers to invite the students to be independent to do the learning process with lecturers as the one who guides the students.

\section{Research Methoodology}

This study is done in one of universities in Bogor, West Java. 10 participants of a class in Faculty Of Teacher Training And Education participated to share their thoughts about PBA in higher education. Qualitative method is used for this study. Qualitative research broadly refers to the category of research approaches that produce findings without relying on quantitative measurements or statistical analysis (Corbin \& Strauss, 2015). The instrument to collect the information is interview question list which is shared through WhatsApp chats because of the condition of Covid-19 social distancing. The data was taken started from May $21^{\text {st }} 2021$ until May $23^{\text {rd }} 2021$.

In the data analysis process, the researcher applied narrative analysis which was followed by the following stages: 1) The Assembly Step, namely the data collected from interviews; 2) Categorized based on theme, namely grouping answers from respondents based on existing themes; and finally 3) Finishing Step, namely drawing conclusions.

\section{Findings and Discussion}

\section{PBA encourages self-regulated learning of students.}

Self-regulated learning is a concept of how a person becomes a manager of himself in his learning activities. The study of SRL has been interesting for many years because it is a fact as mankind to live in a society where lifelong learning is important (Beishuizen \& Steffens, 2011). This is why higher education must always do innovation to make the students have intention to learn more. It is also related to the Laws of The Republic Indonesianumber 12 year 2012about Higher Education that higher education learning methodology must be 
student-centeredbecause as the agent of change, they would devote themselves for society. "Ease to learn the materials because when we look for the material ourselves, we understand it ourselves, it is not always true, and we are confused about where to go if we want to ask. For example: Group A gives a presentation, other groups can join in the study and if confused can ask questions"'(Excerpt 1)

"It is as challenge to understand the material and explain it to others".(Excerpt 2)

Based on the answers of some respondents, it shows that PBA is able to make students learn the materials by themselves. Data from excerpt 1 indicates that by discussing the subject together with friends, it would share various ideas that can improve broadly insight of related materials. The answer of the second respondent also shows that teaching the materials that is learned by themselves to other friends can strengthen their comprehension on mastering the materials. It is also supported by other answers:

"Can be more prepared, better master the material to answer questions"(Excerpt 3)

When students doing presentation, they are assigned to comprehend the materials as best before the lecturer explains in the class because in the session of presentation has Question and Answer time. It could make the presenters read the materials a lot and guess the probably given questions from audiences. Also then, the 4C abilities related to the students' perspectives on how PBA is applicated in classroom, which are criticical thinking and problem solving. When the audience ask question, it motivates the presenter to decide the solution of some cases.

\section{Group presentation as model of $\mathrm{PBA}$ promotes Cooperative Learning Strategies}

Cooperative learning project as an effective English learning procedure related to the 2013 curriculum in the EFL classroom has become the focus of various studies. Cooperative learning project defines as a practice that the students do the given task cooperatively to reach the target of group assignments which is probably not able to be done individually (Gillies, 2016).When cooperative learning tasks are given, each member of groups is trained to overcome problems by discussing and expressing dissimilar point of views. Of the various thoughts, knowledges that are not existing before can be implemented as brand new sciences. Meanwhile, individual learning just focus on self-perspectives where they do not have any improvements. The students are more critical in defining issues because they do not just live in school, but wider environment which needs to be analyzed and evaluated. Below are some responses to support the theme:

"It is building a cooperative attitude among students, like it or not, you have to be active in the discussion process" (Excerpt 4)

"It makes us be more active in doing interaction" (Excerpt 5)

From both answers, it concludes that group presentation assessment make the students do good cooperation to perform the materials. For example, the students discuss to decide who seek the A material, B material, or C material. Also, choose who the leader, secretary, moderator of the presentation are. It engages students to think critically and participate actively in doing the assessment. If it is connected to the abilities of $4 \mathrm{C}$ in 21 st century, PBA has done the parts of collaborative and communication. In Vyogotski words, there are two 
ways how to rate child's cleverness; first at the time they overcome the problems without anyone's assitance, second is at the time they overcome the problems with more able partner (Veer, 2017). The second way results a value that is more open-minded. This means partners or friends in doing the PBA is able to be called as MPA which makes the members of group presentation is trained to be tollerance in stating ideas.

\section{PBA works well depends on teachers' feedback}

A study in Norwey showed that students who were aware of learning goals perceived the teachers' feedback as more useful (Vattøy \& Smith, 2019). Teachers' feedback on students' assessment is necessary to motivate the students straighten the students' comprehension of the materials. Sometimes, not all what students understand from the learning sources are true. This is teachers' role to evaluate the materials which has been conveyed by the presenters, what the things must be impoved? What the things must be removed? What the things must be done for next performance?. If there is no any teachers' feedback, the students are unmotivated to do better for next time, the students do not know what something wrong. It would be brought by them as mindset. Below are supporting utterances based on the theme:

"There are some people who are not serious about PBA, or are not active, and the lecturers don't care, they depend on others". (Excerpt 6)

"The environment is less supportive, such as teachers who are less responsive, less innovator in the classroom so that the delivery of the material is just that and may not develop student creativity". (Excerpt 7)

Depends on the above responses, it points that there is still time when lecturer do not control the discussion as well. The lectures sometime just let the leader of the class to monitor the group presentation without doing evaluation on other days. This happens because the learning model is student-centered. It doesn't mean that the teachers are not involved to achieve the learning goals. Teachers are as facilitators who guide the students to do the learning process. It is also important for teachers to make the rubric or scoring become two parts, individually and generally. The individual score is to assess the student on how he masters the materials which has been divided from group. The general score is how the all students can work in group as well. It is fairer for the students to do the assessment. Below are the responses who state the difficulties working in group:

"Not all of them work in one group, some just accept it". (Excerpt 8)

"Less cohesive, difficult to work together, easier if there is a leader, we must be more active". (Excerpt 9)

From both answers, how if the lecturers do not care about the problems? It is surely the assessment can't hold the principle of realibility because it can disturb students' concentration. There is a gap between student A who is diligent and student B who is lessmotivation.

However, there is also a students who keeps thinking positively about the negative impact of less-teachers' feedback, 
"It can divide groups with the same material, by learning to interact with groups, learn to be sincere when there are not totality in the group". (Excerpt 10)

\section{PBA trains students' public speaking}

A study of speaking skill in English using presentation Pecha Kucha resulted that it helps the students the oral presentation skill (Mabuan, 2017). Public speaking is significant to be used in $21^{\text {st }}$ century because it can help them to share ideas through spoken way. Below is as the supportive response:

"I will make preparations a week before the day, so that it can be conveyed well and exercise courage in conveying something. The point is to practice, practice and practice”. (Excerpt 4$)$

"Dividing the material, the material obtained is understood, so it can convey well if there is sufficient preparation". (Excerpt 8)

These mean that PBA's role to attract the students to transfer the materials in spoken with friends. If it is done frequently, it would make students usual to speak in public. Although, in the early time, it is difficult for some students. However, time by time would be improved for them.

\section{Conclusion}

Performance-Based Assessment in the form of group presentation in higher education have benefits for students as the generation who live in 21 st century which must have the $4 \mathrm{C}$ abilities. This kind of assessment is recommended to be continued as teachers' media to measure students' capability in mastering the subject materials with the orderly monitoring from the side of lecturers.

\section{References}

Atayeva, M., Basikin, M., Kassymova, G. K., Sydyk, L., Triyono, M. B., Arpentieva, M. R., ... \& Vladimirovna, K. Y. (2019). IMPROVING STUDENTS'SELF EFFICACY IN SPEAKING ENGLISH BY USING GROUP-PRESENTATION. Научный журнал «Вестник НАН РК», (6), 222-230.

Bahati, B., Fors, U., Hansen, P., Nouri, J., \& Mukama, E. (2019). Measuring Learner Satisfaction with Formative e-Assessment Strategies. International Journal of Emerging Technologies in Learning, 14(7).

Beishuizen, J., \& Steffens, K. (2011). A conceptual framework for research on self-regulated learning. In R. Carneiro, P. Lefrere, K. Steffens, \& J. Underwood (Eds.), Selfregulated learning in technology enhanced learning environments, (pp. 3-19). The Netherlands: Sense Publishers

Boucher, M., \& Creech, A. (2021). The role of formative and summative assessment in music learning and participation. Routledge international handbook of music psychology in education and the community.

Brown, H. D. (2004). Language Assessment Principles and Classroom Practices. New York: Pearson Education. Inc.

Casebolt, K., \& Zhang, P. (2020). An authentic badminton game performance assessment rubric. Strategies, 33(1), 8-13.

Ellis, S., \& Smith, V. (2017). Assessment, teacher education and the emergence of 
professional expertise. Literacy, 51(2), 84-93.

Erdogan,V.(2019).Integrating 4C skills of 21st century into 4 language skills in EFL classes. International Journal of Education and Research, 7(11),113-124.

Fajriah, Y. N., \& Septiyanti, S. N. A. (2021). The Challenges Encountered by EFL Teachers in Developing Students' 4c Skills in 21st-Century Education. JEPAL-Journal of English Pedagogy and Applied Linguistics, 1(2), 106-121.

Fekry, A., Dafoulas, G., \& Ismail, M. (2019, December). Automatic detection for students behaviors in a group presentation. In 2019 14th International Conference on Computer Engineering and Systems (ICCES) (pp. 11-15). IEEE.

Gillies, R. M. (2016). Cooperative learning: Review of research and practice. Australian Journal of Teacher Education (Online), 41(3), 39-54.

Hannah, K., Elizabeth, F., Kirsteen, H., Anne, L., \& Soumaya, M. (2017). OECD Reviews of Evaluation and Assessment in Education Romania 2017. OECD Publishing.

Hidayatullah, Z., Wilujeng, I., Nurhasanah, N., Gusemanto, T. G., \& Makhrus, M. (2021). Synthesis of the 21st Century Skills (4C) Based Physics Education Research In Indonesia. JIPF (Jurnal Ilmu Pendidikan Fisika), 6(1), 88-97.

Mabuan, R. A. (2017). DEVELOPING ESL/EFL LEARNERS'PUBLIC SPEAKING SKILLS THROUGH PECHA KUCHA PRESENTATIONS. English Review: Journal of English Education, 6(1), 1-10.

Masriani, M., Hairida, H., \& Enawaty, E. (2021). Socialization of 4C and HOTS Based Learning Device for Science Teachers in Paloh. JPKM (Jurnal Pengabdian Kepada Masyarakat) UNTAN, 4(1), 30-37.

Muradkasimova, K. (2021). THE IMPORTANCE OF DEVELOPING TEACHERS'ASSESSMENT LITERACY COMPETENCE. Philology Matters, 2021(1), 172-187.

Murchan, D., \& Shiel, G. (2017). Understanding and applying assessment in education. Sage.

Newton, J., Williams, M., \& Feeney, D. (2020). Implementing non-traditional assessment strategies in teacher preparation: Opportunities and challenges. Journal of Culture and Values in Education, 3(1), 39-51. https://doi.org/10.46303/jcve.03.01.3

Suyitno, A., Suyitno, H., \& Sugiharti, E. (2021, June). Integration of 4C competencies in online mathematics learning in junior high schools during the covid-19 pandemic. In Journal of Physics: Conference Series (Vol. 1918, No. 4, p. 042083). IOP Publishing.

Syah, R., \& Hermawati, I. (2018). Evaluation of Children's Performance Assessment in PreSchool. The 2nd International Conference On Child-Friendly Education (ICCE) 2018.

Van Ginkel, S., Laurentzen, R., Mulder, M., Mononen, A., Kyttä, J., \& Kortelainen, M. J. (2017). Assessing oral presentation performance: Designing a rubric and testing its validity with an expert group. Journal of Applied Research in Higher Education.

Vattøy, K.-D., \& Smith, K. (2019). Students' perceptions of teachers' feedback practice in teaching English as a foreign language. Teaching and Teacher Education, 85, 260268. doi:10.1016/j.tate.2019.06.024

Veer, R.V.D. (2017). Lev Vyogotsky. London, Oxford: Bloomsburry.

Wyatt-Smith, C. (2018). Graduate teacher performance assessment: An intervention project at the intersection of standards, professional knowledge and assessment. Melbourne: ACER 


\section{APPENDIX}

Below is the interview list that is used for this study:

\begin{tabular}{|l|l|}
\hline No. & Questions \\
\hline 1. & What do you feel about PBA application in class? \\
\hline 2. & What advantages can you get from PBA? \\
\hline 3. & What disadvantages can you get from PBA? \\
\hline 4. & How do you solve problems in PBA? \\
\hline 5. & How do you prepare yourself to do PBA? \\
\hline
\end{tabular}

